\title{
Residential Energy-Efficient Technology Adoption, Energy Conservation, Knowledge, and Attitudes: An Analysis of European Countries
}

\author{
Bradford Mills ${ }^{a}$ and Joachim Schleich ${ }^{a, b, c}$ \\ a Virginia Polytechnic Institute and State University, 314 Hutcheson Hall, Blacksburg \\ 24061-0401, Virginia, USA \\ *bfmills@vt.edu (corresponding author) \\ Phone: + 1540231 6461; fax: +1 (540) 231-7417 \\ ${ }^{\mathrm{b}}$ Fraunhofer Institute for Systems and Innovation Research, Breslauer Straße 48, 76139 \\ Karlsruhe, Germany \\ ${ }^{\circ}$ Grenoble Ecole de Management, 12, rue Pierre Sémard - BP 127 - 38003 Grenoble \\ Cedex 01, France
}

\begin{abstract}
:
Relationships between a number of measures of household energy use behavior are estimated using a unique dataset of approximately 5,000 households in ten EU countries and Norway. Knowledge of energy consumption and energy-efficient technology options is found to be associated with household use of energy conservation practices, but not with adoption of energy-efficient technologies. Household characteristics also influence household energy use behavior. Younger household cohorts are more likely to adopt energy-efficient technologies and energy conservation practices and place primary importance on energy savings for environmental reasons, while households with a high share of elderly members place more importance on financial savings. Education also influences attitudes towards energy conservation. Low education households indicate they primarily save electricity for financial reasons, while high education households indicated they are motivated by environmental concerns. Significant country differences also exist. Households in transitioning Eastern European countries generally have lower levels of energy-efficient technology adoption, but strong propensities to employ energyconservation practices, and place less importance on saving electricity for environmental reasons compared to households in Western European countries. EU policies to promote residential adoption of energy-efficient technologies and energy conservation practices must be sensitive to both cross-country and intra-county variations in household energy use behavior.
\end{abstract}

Keywords: Household energy-efficiency; technology adoption; energy conservation 


\section{Introduction}

The EU has set an indicative target for energy efficiency as part of the climate and energy package that includes binding 2020 EU27 targets for greenhouse gas emissions and renewable energy use (European Commission 2008, European Council 2006, 2007). The EU seems on track to achieve required 20 percent reductions in greenhouse gas emissions in 2020 compared to 1990 levels, along with 20 percent renewable energy use in final energy consumption. However, the energy efficiency target of 20 percent primary energy savings in 2020 compared to business-as-usual development may be missed without further measures (COM(2008) 772 final; Ecofys and Fraunhofer ISI 2010; COM(2011) 109 final, SEC (2011) 275). Efficiency gains in the household sector, which accounts for about 25 percent of total final energy consumption and 29 percent of total electricity use in the EU27 (Bertoldi and Atanasiu 2009), are expected to be a key factor in determining whether or not the EU meets its efficiency targets. According to the European Council Action Plan for Energy Efficiency (European Council 2006) residential energy-savings of 27 percent may be achieved compared to expected baseline growth by 2020 through the adoption of cost-efficient residential energy efficient technologies and conservation practices. In a more recent study, Fraunhofer ISI et al. (2009) estimate that the residential sector may cost-effectively save about 19 percent of final energy compared to the baseline in 2020 with additional policies to overcome barriers to adoption of existing technologies. The bulk of these savings will come from improved thermal insulation, but 7 percent of energy savings are expected to accrue from the adoption of energy efficient household appliances (including lighting). Additional policy measures to enhance adoption can increase the energy efficient household appliance contribution to final energy savings to about 17 percent compared to business as usual in 2020 . 
In general, residential energy policies can be employed to both enhance the uptake of improved energy conservation practices (e.g. switching off lights when leaving a room, adjust indoor temperature at night, reduce heat in unused rooms, only use dishwasher and washing machines at full load, put lid on pots) and increase for adoption of energy efficient technologies (e.g. insulation of outer walls, attic, window glazing; energyefficient heating system; purchase energy efficient household appliances, office equipment or light bulbs). The formulation of effective and well targeted residential energy policies to increase both conservation and technology adoption must be based on a sound understanding of how technology adoption, conservation practices, energy use knowledge, and attitudes towards energy conservation are associated with household characteristics. In a diverse regional organization like the EU, it is also essential to identify country-specific differences in energy-saving technology adoption and energy conservation practices in order to generate an appropriate combination of common and country-specific policies.

This paper employs a unique dataset of almost 5,000 households from eleven European countries (ten EU countries and Norway) to identify differences in residential energy efficient technology adoption and energy conservation behavior due to household characteristics and country of residence. Relationships between household characteristics and household knowledge of energy use and energy-saving technologies and household attitudes towards energy conservation are also explored with the dataset. The research is, to our knowledge, the first attempt to analyze residential energy conservation technologies, behavior, and attitudes jointly for a broad cross-section of European countries. 
The remainder of the paper is organized as follow. After a review of the literature in section two, section three lays out the empirical specification of the model. Section four provides a description of the data. Results are presented in section five and the final section discusses the main findings and concludes.

\section{Literature overview}

Household level analyses of the adoption of energy efficient technologies and conservation practices are rather scarce and are concentrated on the US, Canada, and several individual EU countries. Dillman et al. (1983) and Black et al. (1985) examine (primarily thermal) energy efficiency investments and adjustments in behaviour using surveys of the Western States of the US and Massachusetts, respectively, while Walsh (1989) and Long (1993) focus on the adoption of thermal energy measures for the entire US. Curtis et al. (1984) analyze technology adoption and behavioral practices aimed at reducing household thermal energy and electricity use in Regina (Canadian Province of Saskatchewan) and Fergusen (1993) analyses the adoption of retrofitting measures for all of Canada. Brechling and Smith (1994) and Caird et al. (2008) explore insulation, heat generation and lighting technologies in UK households. Barr et al. (2005) use data on selected technological measures and conservation practices related to household thermal energy and electricity use for the UK county of Devon. Poortinga et al. (2003, 2004) include an extensive list of technological measures and behavioral practices associated with thermal energy and power use in the Netherlands, while Scott (1997) focuses on several technology measures (attic and hot water cylinder insulation and lighting) in a survey of Irish households. For Germany, Mills and Schleich (2010a) and Mills and Schleich (2010b) explore the adoption of energy-efficient household appliances 
and of compact fluorescent light bulbs (CFLs), respectively. Finally, for Sweden Linden et al. (2006) consider a set of behavioral practices, Mahapatra and Gustafsson (2008) analyze the adoption of heating systems, while Nair et al. (2010) consider several thermal energy investments as well as behavioral practices related to electricity and thermal energy use.

Most studies find that adoption of energy efficient measures and behavioral practices are typically associated with costs (for investments and energy use), habits, and routines, which differ across measures, households and regions. Curtis et al. (1984) were among the first to point out that energy-savings measures may be distinguished in low-cost or no-cost measures which do not involve capital investment but rather behavioural change and high-cost measures which require capital investment and involve technical changes in the residence. Similarly, from a behavioural perspective it is much easier to change a singular investment decision such as purchasing a CFL than to change daily behaviour such as switching off lights after leaving a room (e.g. Gardner and Stern 1996). Also, while energy savings resulting from technology adoption tend to have long run effects, behavioural measures may only have transitory effects (e.g. Abrahamse et al. 2005). Barr, Gilg and Ford (2005) also distinguish explicitly between habitual behaviour and technology adoption and stress that energy savings behaviour needs to be considered within the broader context of environmental behaviour. Adoption of energy efficient technologies and conservation measures is usually associated with reduced emissions of greenhouse gases and other pollutants that benefit others without compensating the energy savers. In this context, motives for energy savers' provision of a public good include altruism, empathy, the 'warm glow of giving' (Andreoni 1990) and prestige (Harbaugh 1998). 
Studies on the adoption of energy efficient measures in households are typically based on different, partially overlapping concepts from economics (including behavioral economics), psychology and sociology. Insights from the psychology and sociology literature are employed to analyze the impact of psychological variables such as values, beliefs, or attitudes towards energy conservation as well as the impact of social norms shared by relevant groups on energy efficiency activities (Gardner and Stern 1996). The thrust of this literature suggests that attitudes towards energy conservation or environmental motivation in general may at best explain a modest share of the variation in household energy consumption or adoption of energy savings measures (e.g. Viklund 2004, Sjöberg and Engelberg 2005, OECD 2008, Di Maria, Ferreira, and Lazarova 2010). Environmental behaviour is not only driven by motivational factors, but also determined by contextual factors, including opportunities, individual abilities, status, comfort, and effort (Poortinga 2004, Stern 2000). In particular, attitudes do not directly determine behavior. Instead they affect intentions which in turn form people's actions. According to Ajzen and Fishbein (1980, p. 239) intentions are not only influenced by attitudes but also by social pressure and perceived behavioural control. In other words, attitudes towards environment may not necessarily lead to good intentions, and stated good intentions may not necessarily lead to good actions. Social norms, lack of information about the implications of alternative actions on the environment, or institutional and economic factors may act as barriers towards actual implementation (Van Raaij and Verhallen 1983). Kammerer (2009) emphasizes the importance of additional customer benefits as a key factor in the demand for "green" products. These additional benefits include energy (and other) cost savings, improved product quality (durability and reliability) or improved repair, upgrade, and disposal possibilities. 
Based on the empirical literature, factors influencing energy saving activities may generally be categorized as characteristics of the household (education, income, number of children, age, renter or owner), characteristics of the residence (multi-family home, size), characteristics of the measure (behavioral or technological, costs, performance, energy use), economic factors (energy prices), availability and quality of information, weather and climate factors, and attitudes towards energy savings or towards the environment. We will briefly summarize the main findings of the literature, focusing more heavily on factors which are relevant for the subsequent empirical part of the paper. ${ }^{1}$

\subsection{Education}

Most studies suggest a positive correlation between education level and energy-saving activities, including the econometric analyses by Hirst and Goeltz (1982), Brechling and Smith (1994) or Scott (1997) for energy efficient technology adoption. Exceptions include Ferguson (1993) and Mills and Schleich (2010a). Among the reasons for a positive correlation are that education reduces the costs of information acquisition (Schultz, 1975). Alternatively, education as a long term investment may be correlated with a low household discount rate and, thus, be positively associated with energysaving measures that require higher up front investment costs for energy cost savings that materialize over time. Attitudes towards the environment as well as social status, lifestyle (Lutzenhiser 1992, 1993, Weber and Perrels 2000), and belonging to a particular social milieu group approving of environmentally friendly behaviour (e.g. Brand

\footnotetext{
${ }^{1}$ Nair et al. (2010), Brohmann et al. (2009) and Sardianou (2007) include recent surveys of the empirical literature on household energy saving behavior and Wilson and Dowlatabadi (2007) provide a conceptual overview from economics, psychology, sociology and innovation studies.
} 
1997) also tend to be positively related with education. Torgler and Garçia-Valiñas (2007, p. 538) cite several sources suggesting that higher education levels are associated with higher preferences for environmental conservation.

\subsection{Age and Household Composition}

The majority of empirical studies analyzing the household up take of energy efficiency measures and practices control for age (of the household head), but only a few studies account for household composition by age groups. Older household heads may be less likely to adopt energy efficient technologies because the expected rate of return is lower than for households with younger heads. This line of reasoning is supported by the findings of Curtis et al. (1984), Walsh (1989), Poortinga et al. (2003) and Mahapatra and Gustavsson (2008). On the other hand, younger households may be more likely to move and hence be less inclined to invest in energy efficiency improvements, in particular if these measures become an integral part of the built environment. Combining these perspectives, middle aged households should be most likely to adopt capital-intensive energy efficiency measures (e.g. Mills and Schleich, 2010a), particularly if the technologies are structurally linked to the building. For measures with low up-front costs (e.g. light bulbs) and for behavioral measures the expected impact of age is less clear. Lutzenhiser (2002) finds that older households are less likely to adapt behaviour while in Mills and Schleich (2010b) adoption intensity of energy efficient light bulbs increases at a declining rate with age. On the other hand, as suggested by Carlsson-Kanyama et al. (2005), younger households tend to prefer up-to-date technology, which is usually also

more energy efficient. In sum, the relationship between age and the take-up of energy savings measures is likely to be nonlinear and technology specific. 
Lower adoption of energy efficient technologies by elder households may also interact with the cohort's fewer years of formal education, and lower levels of information on energy savings measures. For example, survey results by Linden et al. (2006) for Sweden indicate that younger people have better knowledge about energy-efficient measures than older people. Clustering individuals into different types, the findings by Barr et al. (2005) for the UK, and by Painter et al. (1981) and by Ritchie et al. (1981) for the US suggest that "energy savers" are older. Addressing environmental concerns directly, the studies by Whitehead (1991) and by Carlsson and Johansson-Stenman (2000) - cited by Torgler and Garçia-Valiñas (2007) - found that willingness to pay for environmental protection decreases with age, arguably because a shorter expected remaining lifetime results in lower expected benefits from environmental preservation. Torgler and Garçia-Valiñas (2007) for Spain and Torgler et al. (2008) for 33 Western European countries also observe a negative correlation between age and environmental attitudes/preferences. Similarly, according to Howell and Laska (1992) younger people in the US are more concerned about the environment than older people. However, as Torgler and Garçia-Valiñas (2007) also point out, age effects need to be decomposed into a life cycle effect which stems from being in a particular stage of life, and into a cohort effect which results from belonging to a particular generation with generationspecific experiences, socialization, and economic conditions (e.g. "flower power generation" versus "baby boomers"). Thus, depending on the timing and the region of the survey, age may turn out to have quite different effects on households' adoption of energy-efficient measures. Young children in the household may also impact adoption, as parents may be more concerned about short and long run local and global environmental effects that will influence current and future wellbeing of their children. Dupont (2004) finds that the number of children is positively related to the adoption of 
energy-efficient technologies and conservation behavior, but Torgler et al. (2008) do not find children to generate a positive shift in parental preferences for environmental conservation.

\subsection{Information}

Households' information on energy consumption, conservation opportunities and the energy performance of technologies is expected to affect the adoption of energy-efficient technologies. Availability and quality of information about the levels and patterns of current energy consumption depends on the level of metering, the information content of utility bills, and households' willingness and ability to analyse this information. Similarly, households need to be aware of and able to evaluate energy efficiency opportunities (e.g. Schipper and Hawk 1991). For example Scott (1997) observes that household knowledge about potential energy savings is associated with higher take-up of energy efficient technologies. Typically, labelling schemes such as those implemented in the EU and US for household appliances are cost-effective measures to overcome barriers related to information and search costs, or to bounded rationality on the part of appliance purchasers (Sutherland 1991, Howarth et al. 2000). Evaluation studies based on aggregate observed data find that the existing energy labelling programs for household appliances in the US, the EU and Australia are effective in terms of energy and carbon reductions (e.g. Sanchez et al., 2008; Lane et al., 2007; Banerjee and Solomon, 2003; Schiellerup, 2002; Bertoldi, 1999; Waide, 2001; Waide, 1998). Sammer and Wüstenhagen (2006) conduct survey-based conjoint analyses to analyze consumers' stated choices for washing machines in Switzerland and observe that eco-labelling affects consumers' purchasing decisions. Mills and Schleich (2010a) find that socioeconomic factors like higher education levels, higher income, larger households, and 
higher electricity prices are positively correlated with respondents' knowledge about the energy efficiency label of appliances. Similarly, Murry and Mills (2011) find in the US household characteristics have a greater impact on EnergyStar label awareness than on the uptake of EnergyStar appliances. As for the impact of information campaigns, Reiss and White (2008) observe that consumers respond to both energy prices and information campaigns to reduce energy consumption, although - consistent with the weak correlation between attitude and conservation efforts pointed out above - a survey by the OECD (2008) concludes that information campaigns are not as effective as expected. Households often ignore mass information, but are more likely to respond to well-targeted, direct information (Lutzenhiser 1993). Similarly, based on stated behaviour in Swedish households the findings by Ek and Söderholm (2010) confirm that providing more concrete information on energy savings measures is likely to be more effective than rather general information. In sum, information may improve the level and the quality of knowledge on energy conservation measures, but improved information need not necessarily result in energy conservation.

\section{Empirical specification}

This paper focuses on establishing the empirical relationship between household decision variables (adoption of energy efficient technologies, use of energy conservation practices in the home, knowledge of level of energy use and energy saving options, and preferences for energy savings for environmental and for financial reasons) and household characteristics and country specific effects. Specifically, we econometrically estimate reduced form regression models employing these sets of dependent and independent variables. 


\section{Dependent Variable Measures}

Household adoption of energy efficient technologies is characterized by two alternative measures. The first measure (buyind) is an index of adoption of energy efficient "white" appliances (refrigerators, freezers, dishwashers, washing machines, and dryers), office equipment, and light bulbs generated by factor analysis. White appliances account for about 25 percent of residential electricity use in the EU27, lighting for 11 percent, and computers for about 3 percent (Bertoldi and Atanasiu 2009, p. 13f). In the EU all major white appliances are classified under a common energy labeling framework from most efficient (class $A++)$ to least efficient (class-G). The index includes a measure of the energy class of the above mentioned major white appliances. Many households did not report appliance energy classes, either because the appliance was purchased before the rating system was implemented or because the energy class was not known by the respondent. $^{2}$ In these cases the energy class is recorded as a zero. However, separate indicator variables are also included in the factor analysis to indicate that the energy class of the appliance was not known. Adoption of energy efficient office technologies is measured as the purchase of EnergyStar labeled products. Adoption of the third technology type, energy efficient light bulbs, is simply measured as the share of household bulbs that are energy efficient compact fluorescent bulbs (CFLs).

The CFL share of all household bulbs (cflshare) is used as an alternative measure of energy efficient technology adoption. The sole CFL share measure has the advantage of

\footnotetext{
${ }^{2}$ Implementing directives were published by the EU in 1994 for refrigerators, freezers and their combinations, in 1995 for washing machines, and in 1997 for dishwashers. In 2004, the labeling scheme for cold appliances was extended to $A+$ and $A++$ to account for substantial energy efficiency improvements in the highest energy efficiency category. Appendix table A.1 provides information on the dates that implementation directives became law in specific countries.
} 
simplicity. But, by the same token, CFL share is a less comprehensive measure of household adoption of energy efficient technologies.

A household knowledge index (knowledge) is also generated through factor analysis. The index is based on three indicators of household knowledge of energy use; if the household knows its annual electricity consumption, if the household correctly knows what the EnergyStar label stands for, and if the household knows that computer monitor screensavers do not save electricity.

Similarly, a household energy conservation index (effindex) is generated through factor analysis based on six indicators of energy conservation practices in the home. These practices are 1) fully loading the washing machine every time; 2) cooking frequently with a pressure-cooker; 3) turning off the lights every time a room is vacated; 4) turning off the TV when it is not being watched; 5) setting energy saving features on the computer monitor; and 6) setting energy saving features on the computer desktop.

Household attitudes toward energy savings are captured through household indicators of the stated importance of energy savings for environmental (greenhouse gas reduction) reasons (goalghe) and financial reasons (goalsav). Specifically, attitudes are measured by households indicating that they felt it was 'most important' to save electricity for that reason.

By construction the indexes buyind, knowledge and effindex take on values between -1 and 1, while goalghe and goalsav are dichotomous. 


\section{Independent variables}

The independent variables employed to establish relationships with the above indexes are driven largely by data availability. Education is measured for the most educated member of the household as a continuous scale on the range of no high-school, highschool, trade or vocational school, and university. Household composition is measured by the number of members less than 12 years of age (It12), the number of members 13 to 18 years of age (to18), the number of members 19 to 65 years of age (to65), and the number of members over 65 years of age (gt65). Country specific effects are captured through country indicators for Belgium, Bulgaria, The Czech Republic, Denmark, France, Greece, Hungary, Norway, Portugal, and Romania, with Germany being the base country.

Relationships with continuous indexes are estimated via OLS regression models. Given the large number of observations with a response of zero, relationships with the CFL share of household light bulbs regression are estimated with a Tobit model. Similarly, relationships with the dichotomous environmental attitude indicators are estimated with Probit models. 


\section{Data}

The study dataset is generated from the Residential Monitoring to Decrease Energy Use and Carbon Emissions in Europe Project (REMODECE) survey conducted in eleven countries in 2007. All countries used a common survey instrument that was translated into the local language. The goal was to survey at least 500 households in each country. However, there was considerable variation in country data collection strategies. Belgium, The Czech Republic, Denmark, Norway, and Portugal relied primarily on online internet based surveys. Bulgaria and Germany relied primarily on mail surveys, while France used telephone interviews and Hungary and Romania used face-to-face interviews. Greece used a mixture of face-to-face, online, email, and mail surveys. Data are available from the project website at: http://www.isr.uc.pt/ remodece/. The overall sample contains 4,902 households. ${ }^{3}$ The distribution of country sample sizes from the website data ranges from Romania with 622 households to France with 100 households.

Descriptive statistics for the variables employed in the study are presented in table 1. As expected, the means of all the dependent variables generated through factor analysis (buyind, knowledge, effindex) are zero. The cflshare variable indicates that the average share of household bulbs that are CFLs is 16.6 percent, with 43 percent of households having no CFL bulbs. For attitudes, 19.6 percent of households indicated that energy savings was most important for greenhouse gas reductions and 63.2 percent indicated that energy savings was most important for financial reasons.

\footnotetext{
${ }^{3}$ Information on CFL bulb shares is missing for an additional 6 households, leaving sample sizes for the energy-efficient technology adoption measures of 4,896 households.
} 
Table 1: Descriptive Statistics

\begin{tabular}{|c|c|c|c|}
\hline Variable & Description & Mean & St. Dev. \\
\hline buyind & Energy-efficient technology adoption index & 0.000 & 0.950018 \\
\hline cflshare & Share of bulbs that are CFLs & 0.166 & \\
\hline knowledge & Knowledge of energy use and conservation measures index & 0.000 & 0.284257 \\
\hline effindex & Use of energy conserving practices index & 0.000 & 0.80055 \\
\hline goalghe & Energy savings is most important for greenhouse gas reductions $=1$ & 0.196 & \\
\hline $\begin{array}{l}\text { goalsav } \\
\text { Independent }\end{array}$ & Energy savings is most important for financial reasons $=1$ & 0.632 & \\
\hline education & $0=$ less than high school, $1=$ high school, $2=$ trade or vocational, $3=$ university & 2.152 & 0.988381 \\
\hline It12 & Number of household members less than 12 years of age & 0.360 & 0.726682 \\
\hline to18 & Number of household members 12 to 18 years of age & 0.222 & 0.532931 \\
\hline to65 & Number of household members 19 to 65 years of age & 1.981 & 1.010384 \\
\hline gt65 & Number of household members greater than 65 years of age & 0.209 & 0.534867 \\
\hline belgium & Resident of country $=1$ & 0.109 & \\
\hline bulgaria & & 0.104 & \\
\hline czech & & 0.098 & \\
\hline denmark & & 0.085 & \\
\hline france & & 0.020 & \\
\hline germany & & 0.111 & \\
\hline greece & & 0.085 & \\
\hline hungry & & 0.100 & \\
\hline norway & & 0.052 & \\
\hline portugal & & 0.109 & \\
\hline romania & & 0.127 & \\
\hline \multicolumn{2}{|c|}{ Number of observations: } & 4,896 & \\
\hline
\end{tabular}




\section{Results}

Two sets of regression results are presented. The first set includes each dependent variable as a function of all independent variables. The second set of regression results presents the technology adoption indexes and the energy conservation index as a function of all independent variables, as well as each other and the knowledge and attitudes indexes.

Results from the first set of regressions appear in table 2. The index for adoption of energy efficient household technologies (buyind) increases with education, number of children under 12 years of age, and number of adults 19 to 65 years of age. The relationship between children under 12 and the adoption of energy efficient technologies may occur because children increase households concerns about the future environment. Alternatively, the result may occur because children under 12 years of age tend to live in households with young to middle-age heads, who in turn have a higher propensity to purchase energy efficient technologies. The statistically negative parameter estimate for the number of household members over 65 years of age provides support for the later explanation. Considerable variation in country specific effects is also found, compared to the country benchmark of Germany, even after controlling for household characteristics. Belgium, Denmark, France, and Norway are estimated to have higher household propensities to adopt energy efficient technologies than Germany, while Bulgaria, Greece, Hungary, and Romania are estimated to have lower propensities. 
Table 2: Regression of indexes on household characteristics and countries

\begin{tabular}{|c|c|c|c|c|c|c|c|c|c|c|c|c|}
\hline & \multicolumn{2}{|l|}{$\begin{array}{l}\text { OLS Estimates } \\
\text { buyind }\end{array}$} & \multicolumn{2}{|c|}{$\begin{array}{l}\text { Tobit Estimates } \\
\text { cflshare }\end{array}$} & \multicolumn{2}{|c|}{$\begin{array}{l}\text { OLS Estimates } \\
\text { knowledge }\end{array}$} & \multicolumn{2}{|l|}{$\begin{array}{l}\text { OLS Estimates } \\
\text { effindex }\end{array}$} & \multicolumn{2}{|c|}{$\begin{array}{l}\text { Probit Estimates } \\
\text { goalghe }\end{array}$} & \multicolumn{2}{|c|}{$\begin{array}{l}\text { Probit Estimates } \\
\text { goalsav }\end{array}$} \\
\hline & $\begin{array}{l}\text { Parameter } \\
\text { Est. }\end{array}$ & $\begin{array}{l}\text { Stand. } \\
\text { Err. }\end{array}$ & $\begin{array}{l}\text { Parameter } \\
\text { Est. }\end{array}$ & $\begin{array}{l}\text { Stand. } \\
\text { Err. }\end{array}$ & $\begin{array}{l}\text { Parameter } \\
\text { Est. }\end{array}$ & $\begin{array}{l}\text { Stand. } \\
\text { Err. }\end{array}$ & $\begin{array}{l}\text { Parameter } \\
\text { Est. }\end{array}$ & $\begin{array}{l}\text { Stand. } \\
\text { Err. }\end{array}$ & $\begin{array}{l}\text { Parameter } \\
\text { Est. }\end{array}$ & $\begin{array}{l}\text { Stand. } \\
\text { Err. }\end{array}$ & $\begin{array}{l}\text { Parameter } \\
\text { Est. }\end{array}$ & $\begin{array}{l}\text { Stand. } \\
\text { Err. }\end{array}$ \\
\hline education & 0.070 ** & 0.013 & 0.030 ** & 0.006 & 0.018 ** & 0.004 & 0.128 ** & 0.011 & 0.075 ** & 0.023 & -0.110 ** & 0.021 \\
\hline It12 & 0.142 ** & 0.017 & $0.020^{* *}$ & 0.008 & 0.008 * & 0.005 & 0.024 * & 0.015 & 0.011 & 0.030 & 0.019 & 0.027 \\
\hline to18 & 0.028 & 0.023 & 0.009 & 0.010 & -0.008 & 0.007 & -0.013 & 0.020 & $-0.099 * *$ & 0.042 & -0.009 & 0.036 \\
\hline to65 & 0.076 ** & 0.014 & 0.005 & 0.006 & $0.008^{* *}$ & 0.004 & $0.027^{\star *}$ & 0.012 & -0.025 & 0.025 & 0.001 & 0.022 \\
\hline gt65 & -0.060 ** & 0.026 & -0.004 & 0.012 & $-0.017^{\star *}$ & 0.007 & $-0.117^{* *}$ & 0.022 & $-0.141^{* *}$ & 0.051 & 0.079 * & 0.042 \\
\hline belgium & 0.180 ** & 0.053 & 0.039 * & 0.023 & $-0.062 * *$ & 0.015 & 0.350 ** & 0.046 & -0.031 & 0.097 & -0.965 * & 0.083 \\
\hline bulgaria & $-0.439 * *$ & 0.054 & $-0.184^{* *}$ & 0.026 & $-0.184^{* *}$ & 0.016 & $0.366^{* *}$ & 0.047 & $-0.329 * *$ & 0.106 & 0.031 & 0.087 \\
\hline czech & 0.079 & 0.055 & $0.148^{* *}$ & 0.024 & -0.232 ** & 0.016 & 0.656 ** & 0.048 & 0.170 * & 0.097 & -0.012 & 0.088 \\
\hline denmark & $1.111^{* *}$ & 0.056 & 0.044 & 0.024 & $0.327^{* *}$ & 0.016 & 0.736 ** & 0.048 & $0.892^{* *}$ & 0.092 & -0.149 * & 0.088 \\
\hline france & $0.221^{\star *}$ & 0.092 & 0.021 & 0.041 & -0.034 & 0.026 & 0.679 ** & 0.080 & $0.773^{* *}$ & 0.144 & -0.471 ** & 0.140 \\
\hline greece & $-0.380^{* *}$ & 0.056 & 0.017 & 0.025 & 0.013 & 0.016 & $0.777^{* *}$ & 0.049 & $0.863^{* *}$ & 0.093 & -1.479 ** & 0.094 \\
\hline hungry & $-0.308 * *$ & 0.053 & $0.067^{* *}$ & 0.023 & $-0.219 * *$ & 0.015 & 0.076 * & 0.046 & $-0.552 * *$ & 0.115 & $0.325^{* *}$ & 0.091 \\
\hline norway & $0.175^{\star *}$ & 0.065 & -0.012 & 0.029 & $-0.073^{* *}$ & 0.019 & 0.469 ** & 0.057 & -0.039 & 0.119 & $-0.311^{* *}$ & 0.101 \\
\hline portugal & 0.083 & 0.053 & 0.009 & 0.024 & -0.022 & 0.015 & $0.573^{* *}$ & 0.046 & 0.342 ** & 0.092 & -0.398 ** & 0.083 \\
\hline romania & $-0.300 * *$ & 0.051 & -0.216 ** & 0.024 & $-0.191 * *$ & 0.015 & $0.267^{* \star}$ & 0.044 & $-0.489 * *$ & 0.105 & 0.089 & 0.083 \\
\hline constant & $-0.344^{* *}$ & 0.050 & -0.025 & 0.023 & 0.021 & 0.014 & $-0.721^{* *}$ & 0.043 & $-1.083^{* *}$ & 0.091 & $0.840^{* *}$ & 0.081 \\
\hline Adj. R2 & 0.214 & & & & 0.284 & & 0.159 & & & & & \\
\hline Log-likelih & ood & & -2491.7 & & & & & & -2149.5 & & -2842.4 & \\
\hline
\end{tabular}

Note: * indicates significance at the $p=0.10$ level in a two-tailed t-test. $* *$ indicates significance at the $p=0.05$ level in a two-tailed t-test. 
The more narrow measure of household adoption of energy efficient technologies, the share of household bulbs which are CFLs (cflshare), generally shows a weaker association with household characteristics than for the broader multi-technology index. Education is still positively associated with adoption, but the only household composition variable that remains significant is the positive association with number of children less than 12 years of age. Similarly, Denmark, France, and Norway no long show higher propensities to adopt energy efficient technologies (in this case CFL bulbs) than German households.

Household characteristics also show a similar relationship with the index of household knowledge of energy use (knowledge). Education, number of children under 12 years of age, and number of adults 19 to 65 years of age are positively associated with knowledge, while the number of household members over 65 years of age is negatively associated with the index. Again, the higher level of knowledge may stem directly from age (with young to middle aged households being most likely to have children under 12), or the presence of children household may increase concerns for the future environment. In terms of country effects, the energy use knowledge base in Germany appears to be high with only Denmark having a statistically higher knowledge index after controlling for household characteristics. On the other hand, households in Belgium, Bulgaria, The Czech Republic, Hungary, Norway, and Romania have lower knowledge indexes than in German.

Somewhat surprisingly, regression results for the index for use of energy conservation practices (effindex) in the home look rather different from those for the technology adoption and knowledge indexes. The conservation practice index increases with education, number of children less than 12 years of age, and adults 19 to 65 years of 
age, and decreases with adults over 65 years of age in the household. However, all sample countries have a higher index than Germany after controlling for these characteristics. ${ }^{4}$ The results suggest that in a cross-country perspective a high level of knowledge of energy use and available energy-saving technologies in a country does not imply the country will also show high propensities for energy conservation behavior. This result could potentially arise from the 'rebound effect', where households respond to increased energy efficiency with increased energy usage or decreased conservation and, thereby, offset some of the technology induced gains (Sorrell 2007, van den Bergh 2011).

In terms of attitudes, the propensity to state electricity savings is most important for greenhouse gas reductions increases with education. However, the propensity decreases with the number of children 12 to 18 years of age and number of adults over 65 years of age. Again, the result implies that stated environmental concerns are more prevalent among young to middle age household cohorts. Stated importance of electricity savings for green house gas reductions also appears to be lower in Eastern European countries, with Bulgaria, Hungary, and Romania expressing lower importance compared to Germany. On the other hand, the stated importance of electricity savings for greenhouse gas reductions tends to be higher in The Czech Republic, Denmark, France, Greece, and Portugal than in Germany.

The results look very different when estimating associations with the stated importance of electricity reductions for financial savings. The probability of stating financial savings

\footnotetext{
${ }^{4}$ German households in the dataset report relatively low levels of use of energy-saving 'sleep' modes on computer monitors and desktops, as well as a low propensity to 'always' turn the lights off when leaving a room. These variables are given the greatest weight in generating the efficiency index via factor analysis.
} 
as the most important reason decreases with education, possibly reflecting the higher emphasis put on cost savings in low education - low income households. On the other hand, the stated importance of financial savings increases with the number of family members over 65 years of age. This result may again reflect lower income levels in elderly households or may stem from greater frugality with age. In terms of country effects, Germans appear to put the greatest importance on electricity savings for financial reasons, with Belgium, Denmark, France, Greece, Hungary, Norway, and Portugal all showing lower propensities to state financial savings as the most important reason for saving electricity.

The second sets of regressions presented in table 3 specify the energy efficient technology adoption indexes and the energy conservation indexes as functions of each other, as well as other dependent variable measures of household knowledge and attitudes towards energy savings. ${ }^{5}$ Household characteristics and country effects are also retained in these specifications. For the energy efficient technology adoption index regression, the impacts of household characteristics remain largely unchanged from the regression that excludes the other indexes in table 2. Although, the negative parameter estimate for the number of adults in the household over 65 years of age is no longer statistically significant at conventional levels in this specification. Country specific effects are also slightly muted, with households in France and Norway no longer having statistically different propensities to adopt energy efficient technologies compared to

${ }^{5}$ Indexes represent household decisions and are arguably endogenous when included as independent variables. Their parameter estimates should be viewed as correlations rather than causations. It is also worth noting that parameter estimates for the original set of independent variables remain virtually unchanged in table 3 , suggesting that their estimates are not influenced by the introduction of the potentially endogenous variables. 
Table 3: Relationships between indexes, household characteristics, and countries

\begin{tabular}{|c|c|c|c|c|c|c|}
\hline & \multicolumn{2}{|c|}{$\begin{array}{l}\text { OLS Estimates } \\
\text { buyind }\end{array}$} & \multicolumn{2}{|c|}{$\begin{array}{l}\text { Tobit Estimates } \\
\text { cflshare }\end{array}$} & \multicolumn{2}{|c|}{$\begin{array}{l}\text { OLS Estimates } \\
\text { effindex }\end{array}$} \\
\hline & $\begin{array}{l}\text { Parameter } \\
\text { Est. }\end{array}$ & $\begin{array}{l}\text { Stand. } \\
\text { Err. }\end{array}$ & $\begin{array}{l}\text { Parameter } \\
\text { Est. }\end{array}$ & $\begin{array}{l}\text { Stand. } \\
\text { Err. }\end{array}$ & $\begin{array}{l}\text { Parameter } \\
\text { Est. } \\
\end{array}$ & $\begin{array}{l}\text { Stand. } \\
\text { Err. }\end{array}$ \\
\hline education & 0.048 ** & 0.013 & 0.023 ** & 0.006 & 0.117 ** & 0.011 \\
\hline It12 & $0.137 * *$ & 0.017 & 0.019 ** & 0.008 & 0.004 & 0.015 \\
\hline to18 & 0.033 & 0.023 & 0.012 & 0.010 & -0.012 & 0.020 \\
\hline to65 & $0.072 * *$ & 0.014 & 0.004 & 0.006 & 0.017 & 0.012 \\
\hline gt65 & -0.038 & 0.025 & 0.005 & 0.012 & $-0.105^{\star *}$ & 0.022 \\
\hline belgium & 0.144 ** & 0.054 & 0.021 & 0.024 & $0.373 * *$ & 0.046 \\
\hline bulgaria & $-0.493 * *$ & 0.055 & $-0.198^{* *}$ & 0.026 & $0.449 * *$ & 0.048 \\
\hline czech & -0.035 & 0.056 & 0.112 ** & 0.025 & $0.657^{* *}$ & 0.048 \\
\hline denmark & $0.951^{* *}$ & 0.059 & -0.015 & 0.026 & 0.513 ** & 0.052 \\
\hline france & 0.093 & 0.092 & -0.030 & 0.041 & $0.627^{* *}$ & 0.079 \\
\hline greece & -0.506 ** & 0.059 & -0.037 & 0.026 & 0.832 ** & 0.050 \\
\hline hungry & $-0.314^{* *}$ & 0.053 & 0.069 ** & 0.024 & 0.142 ** & 0.046 \\
\hline norway & 0.103 & 0.065 & -0.035 & 0.029 & 0.465 ** & 0.056 \\
\hline portugal & -0.017 & 0.053 & -0.027 & 0.024 & 0.564 ** & 0.045 \\
\hline romania & $-0.337^{\star *}$ & 0.051 & -0.224 ** & 0.025 & 0.336 ** & 0.044 \\
\hline knowledge & 0.025 & 0.050 & 0.004 & 0.022 & $0.083 *$ & 0.043 \\
\hline effindex & 0.176 ** & 0.016 & $0.051^{* *}$ & 0.007 & & \\
\hline buyind & & & & & 0.132 ** & 0.012 \\
\hline goalghe & $0.085 * *$ & 0.033 & 0.070 ** & 0.015 & $0.183^{* *}$ & 0.029 \\
\hline goalsav & $0.065^{* *}$ & 0.028 & 0.010 & 0.013 & $0.110^{* *}$ & 0.024 \\
\hline constant & -0.282 ** & 0.057 & -0.005 & 0.026 & $-0.789 * *$ & 0.048 \\
\hline Adj. R2 & 0.234 & & & & 0.188 & \\
\hline Log-likelihood & & & -2453.8 & & & \\
\hline
\end{tabular}

Note: * indicates significance at the $p=0.10$ level in a two-tailed t-test. ** indicates significance at the $p=0.05$ level in a two-tailed t-test. 
households in Germany. Interestingly, the knowledge index is not correlated with technology adoption. This result suggests that the provision of knowledge on energy use and energy saving technology options is likely to have only a limited impact on residential energy-efficient technology adoption. By contrast, the index for use of energy conserving practices in the home shows a very strong positive association with the adoption of energy efficient technologies. The parameter estimates for both attitude indexes are also positive, suggesting that adoption of energy efficient technologies are motivated by both strong environmental and strong financial concerns.

Regression parameter estimates for the technology index measured as share of household bulbs that are CFLs are also similar to those from the regression that excludes other indexes for household characteristics. However, country effects are more muted, with parameter estimates for Belgium, Greece, and Portugal no longer significant. The indicator for importance of electricity savings for financial reasons is also not significant when CFL share is used as the measure of technology adoption, suggesting financial concerns may have had a limited role in the diffusion of CFL bulbs despite the fact that engineering data suggests that potential cost savings are significant.

For the energy conservation practice index, education continues to have a positive impact, while the number of adults in the household has a negative impact. The strong propensity for German households to show a lower index of energy conservation practices compared to households in other countries also remains. Unlike for technology adoption, the knowledge index has a positive impact on the household energy conservation index (albeit significant at the $p=0.10$ level). Not surprisingly, the energy efficient technology adoption index is also positively related to the household energy conservation index. This result suggests the 'rebound effect' may not be strong. 
The indicators for stated importance for greenhouse gas reductions and financial savings in electricity conservation also continue to have positive coefficients.

\section{Discussion and Conclusions}

The regression models employed in this analysis are reduced form in nature and appropriate caution should be employed in attributing causality rather than correlation to parameter estimates. However, several findings have important implications for the design of residential energy policies in Europe. First, knowledge of household energy consumption and energy-efficient technology options is weakly associated with household energy conservation practices, but is not associated with household adoption of energy-efficient technologies. Thus, information campaigns focused strictly on the energy saving characteristics of improved energy efficiency technologies may have a limited impact on diffusion.

On the other hand, strong environmental and financial concerns of households for energy savings can both be used to motivate energy efficient technology adoption. But the results suggest that environmental and financial concerns are associated with different education - income groups. Low education (and presumably low income) households are primarily motivated to save electricity for financial reasons. Household energy conservation and energy-efficient technology adoption campaigns targeted at households with low education and low income levels should, therefore, highlight the financial savings associated with the adoption of improved energy conservation practices and energy efficient technologies. Financial subsidies may also provide disproportionally strong incentives for these households. Higher education - income groups are more motivated to save energy by environmental concerns. Thus, energy conservation and energy efficient technology adoption programs targeted to higher 
education - income groups should focus on highlighting the positive environmental spillovers associated with reduced energy consumption.

As expected, young and middle-aged household cohorts are more amenable to energyefficient technology adoption and energy conservation practices than households composed primarily of older adults. Energy savings attitudes also appear to differ with the age structure of households. Households with younger children place greater importance on energy savings for environmental reasons and households with a greater share of elderly place greater importance on financial savings. Again, this suggests different mechanisms may need to be developed to promote household energy-efficient technology adoption and energy conservation across age-cohorts.

Finally, the results highlight the fact that despite a broadly compatible framework of energy policies across EU countries, significant cross-country variation remains in propensities to adopt energy-efficient technologies and implement energy conserving practices in the home. Households in Eastern European countries generally show lower levels of household energy-efficient technology adoption when compared to Germany and other Western European countries, this may stem in part from later implementation of energy labeling frameworks. Households in Eastern European countries also place less importance on electricity savings for environmental reasons. East - West differences in the use of energy conservation practices appear to be less pronounced, although conservation may again stem from different motivations in the regions. Overall the results suggest that effective EU policies to promote residential energy-efficient technology adoption and energy conservation must be sensitive to country differences. A major challenge will, therefore, be to generate a set of uniform EU energy policies that 
remain flexible enough to address country specific constraints to the household adoption of energy conservation practices and energy efficient technologies.

\section{References:}

Abrahamse, W., Steg, L., Vlek, C., Rothengatter, T. 2005. A review of intervention studies aimed at household energy conservation. Journal of Environmental Psychology, 25, 273-291.

Ajzen, I., Fishbein, M. (Eds.),1980. Understanding attitudes and predicting social behaviour. Prentice-Hall, New Jersey:

Andreoni, J. , 1990. Impure altruism and donations to public goods: A theory of warmglow giving. Economic Journal, 100, 464-477.

Banerjee, A., Solomon B.D., 2003. Eco-labeling for energy efficiency and sustainability: a meta-evaluation of the US programs. Energy Policy, 31, 109-123.

Bertoldi, P., 1999. Energy efficient equipment within SAVE: activities, strategies, success and barriers. Proceedings of the SAVE Conference for an Energy Efficient Millennium. Graz, Austria, 8-10 November (www.eva.wsr.ac.at).

Bertoldi, P. and B. Atanasiu, 2009. Electricity Consumption and Efficiency Trends in the Enlarged European Union. Status Report 2009.

Black, J.S., Stern, P.C., Elworth, J.T., 1985. Personal and contextual influences on household energy adaptations. Journal of Applied Psychology, 70, 3-21.

Brand, K.-W., 1997. Environmental consciousness and behaviour: the greening of lifestyles, in: Redclift, M., Woodgate, G. (Eds.), The International Handbook of Environmental Sociology. Edward Elgar, Cheltenham, pp. 204-217.

Barr, S. Gilg, A.W., Ford, N., 2005. The household energy gap: examining the divide between habitual- and purchase-related conservation behaviours. Energy Policy, 33, $1425-1444$.

Brechling, V., Smith, S., 1994. Household energy efficiency in the UK. Fiscal Studies, $15,44-56$.

Brohmann, B., Heinzle, S., Rennings, K., Schleich, J., Wüstenhagen, R., 2009. What's Driving Sustainable Energy Consumption? A Survey of the Empirical Literature, ZEW Discussion Paper No. 09-013, Mannheim et al.

Caird, S, Roy, R, Herring, 2008. Improving the energy performance of UK households: Results from surveys of consumer adoption and use of low- and zero-carbon technologies. Energy Efficiency, 1, 149-166.

Carlsson, F., Johansson-Stenman, O., 2000. Willingness to pay for improved air quality in Sweden. Applied Economics, 32, 661-669 
Carlsson-Kanyama, A., Linden, A.L., Eriksson, B., 2005. Residential energy behavior: does generation matter? International Journal of Consumer Studies, 29, 239-252:

$\operatorname{COM}(2008) 772$ final. Communication from the Commission - Energy efficiency: delivering the $20 \%$ target.

$\operatorname{COM}(2008) 778$ final. Proposal for a Directive of the European Parliament and the Council on the indication by labelling and standard product information of the consumption of energy and other resources by energy-related products.

COM (2011)109 final. Communication from the Commission to the European Parliament, the Council, the European Economic and Social Committee and the Committee of the Regions - Energy Efficiency Plan 2011.

Curtis, F., Simpson-Housley, P., Drever, S., 1984. Household energy conservation. Energy Policy, 12, 452-456.

Dillman, D., Rosa, E., Dillman, J., 1983. Lifestyle and home energy conservation in the United States: the poor accept lifestyle cutbacks while the wealthy invest in conservation. Journal of Economic Psychology, 3, 299-315.

Di Maria, C., Ferreira, S. and Lazarova, E., 2010. Shedding Light on the Light Bulb Puzzle: The Role of Attitudes and Perceptions in the Adoption of Energy Efficient Light Bulbs. Scottish Journal of Political Economy, 57: 48-67.

Dupont, D.P. (2004): Do children matter? An examination of gender differences in environmental valuation. Ecological Economics, 49, 273-286.

Ecofys and Fraunhfoer Institute for Systems and Innovation Research (Fraunhofer ISI) (2010): Energy savings 2020. How to triple the impact of energy saving policies in Europe. Report commissioned by the European Climate Foundation (ECF) and the Regulatory Assistance Project (RAP). Uetrecht and Karlsruhe.

Ek, K. and Söderholm, P., 2010. The devil is in the details: Household electricity saving behavior and the role of information, Energy Policy 38, 1578-1587

European Commission, 2008. Communication from the Commission to the European Parliament, the Council, the European Economic and Social Committee and the Committee of the Regions - 20-20-20 by 2020 - Europe's climate change opportunity, $\operatorname{COM}(2008) 13$ final.

European Council (2006): Presidency Conclusions of 23/24 March 2006. 7775/1/06 REV1 of 18.05.2006.

European Council, 2007. Presidency Conclusions of the European Council of 8/9 March 2007. 7224/1/07 REV 1 
Ferguson M. R., 1993. Energy-saving housing improvements in Canada (1979 - 82): a nested logit analysis, Environment and Planning A, 25, $609-625$.

Fransson, N., T. Garling, 1999. Environmental Concern: Conceptual Definitions, Measurement Methods, and Research Findings, Journal of Environmental Psychology, $19,369-382$.

Fraunhofer-Institute for Systems and Innovation Research (Fraunhofer ISI), IENERDATA, Institute of Studies for the Integration of Systems ISIS. Technical University Vienna, and Wuppertal Institute for Climate, Environment and Energy WI (2009). Study on the Energy Savings Potentials in EU Member States, Candidate Countries and EEA Countries. Final Report for the European Commission DirectorateGeneral Energy and Transport. EC Service Contract Number TREN/D1/2392006/S07.66640. Karlsruhe/Grenoble/Rome/Vienna/Wuppertal, 15 March 2009, revised. http://ec.europa.eu/energy/efficiency/studies/efficiency_en.htm

Gardner and Stern, 1996. Gardner, Environmental Problems and Human Behaviour, Allyn and Bacon, Boston.

Harbaugh, W. T., 1998. The prestige motive for making charitable transfers. American Economic Review, 88, 277-282.

Hirst, E., Goeltz, R., 1982. Residential energy conservation actions: analysis of disaggregated data. Energy Systems and Policy, 6, 135-150.

Howarth, R.B., Haddad, B.M., Paton, B., 2000. The economics of energy efficiency: insights from voluntary participation programmes. Energy Policy, 28, 477-486.

Howell, S.E., Laska, L.B.,1992. The changing face of the environmental coalition: a research note. Environment and Behavior, 24, 134-144.

Kammerer, D., 2009. The effects of customer benefit and regulation on environmental product innovation. Empirical evidence from appliance manufacturers in Germany. Ecological Economics, 2285-2295.

Kriström, B. and P. Riera, 1996. Is the income elasticity of environmental improvements less than one. Environmental and Resource Economics, 7, 45-55.

Lane, K., Harrington, L., Ryan, P. 2007, Evaluating the impact of energy labelling and MEPS - a retrospective look at the case of refrigerators in the UK and Australia, in: European Council for Energy-Efficient Economy (Paris): Proceedings of the 2007 eceee Summer Study. Saving energy - just do it! La Colle sur Loup, Côte d'Azur, France, 4 - 9 June 2007; 743-751.

Linden, A-L., Carlsson-Kanyama, A., Eriksson, B., 2006. Efficient and inefficient aspects of residential energy behaviour: what are the policy instruments for change? Energy Policy, 34, 1918-1927.

Long, J., 1993. An econometric analysis of residential expenditures on energy conservation and renew-able energy sources. Energy Economics, 15, 232-238. 
Lutzenhiser, L., 1992. A cultural model of the household energy consumption. Energy, 17, 47-60.

Lutzenhiser, L., 1993. Social and behavioral aspects of energy use. Annual Review of Energy and Environment, 18, 247-289

Lutzenhiser, L., 2002, An exploratory analysis of residential electricity conservation survey and billing data, Southern California Edison, Consultant Report, California Energy Commission, May.

Mahapatra, K., Gustavsson, L., 2008. An adopter-centric approach to analyze the diffusion patterns of innovative residential heating systems in Sweden. Energy Policy, $36,577-590$

Mills, B. and Schleich, J., 2010a. What's Driving Energy Efficient Appliance Label Awareness and Purchase Propensity? Energy Policy, 38, 814-825.

Mills, B. and Schleich, J., 2010b. Why Don't Households See the Light? Explaining the Diffusion of Compact Fluorescent Lamps. Resource and Energy Economics. 32, 363378.

Murray, A. and Mills, B., 2011. Read the Label! EnergyStar Appliance Label Awareness and Uptake Among U.S. Consumers. Energy Economics, 33, 1103-1110.

Nair, G., Gustavsson, L. and Mahapatra, K., 2010. Factors influencing energy efficiency investment sin existing Swedish residential buildings, Energy Policy, 38. 2956-2963.

OECD, 2008. Household behaviour and the environment. Reviewing the evidence. OECD. Paris.

Painter, J., Semenik, R., Belk, R., 1983. Is there a generalized conservation ethic? A comparison of the determinants of gasoline and home heating energy conservation. Journal of Economic Psychology, 3, 317-331.

Poortinga, W., L. Steg, C. Vlek und G. Wiersma, 2003. Household preferences for energy-saving measures: a conjoint analysis, Journal of Economic Psychology, 24, 4964.

Poortinga, W., L. Steg, C. Vlek, 2004. Values, Environmental Concern, and Environmental Behavior. A Study Into Household Energy Use. Environment and Behavior, 36 , 70-93

Reiss, P.C., White, M.W., 2008. What changes energy consumption? Process and public pressures. RAND Journal of Economics, 39, 636-663.

Ritchie, J.R.B., McGougall, G.H.G., Claxton, J.D., 1981. Complexities of household energy consumption and conservation. Journal of Consumer Research, 8, 233-242.

Sammer, K., R. Wüstenhagen, 2006.. The influence of Eco-Labelling on Consumer Behaviour - Results of a Discrete Choice Analysis for Washing Machines, Business Strategy and the Environment, 15, 185-199.

Sanchez, M.C., Brown, R.E., Webber, C., Homan, G.K., 2008. Savings estimates for the United States Environmental Protection Agency's ENERGY STAR voluntary product labeling program. Energy Policy, 36, 2098-2108. 
Sardianou, E., 2007. Estimating energy conservation patterns of Greek households. Energy Policy, 35, 3778-3791.

SEC (2011) 275 final. Progress report of the Energy Efficiency Action Plan 2006. Commission Staff Working Report. Accompanying document to the Energy Efficiency Plan 2011, COM(2011) 109.

Schiellerup, P., 2002. An examination of the effectiveness of the EU minimum standard on cold appliances: the British case. Energy Policy, 30, 327-332.

Schipper, L. and Hawk, D., 1991. More efficient household electricity use. Energy Policy, 19, 244-265.

Schultz, T.W., 1975. The value of the ability to deal with disequilibrium. Journal of Economic Literature, 13, 827-46.

Scott, S., 1997. Household energy efficiency in Ireland: a replication study of owner of energy saving items. Energy Economics, 19, 187-208

Shen, J. and Saijo. T. (2007): The Socioeconomic Determinants of Individual Environmental Concern: Evidence from Shanghai Data. OSIPP Discussion Paper 07E003, Osaka School of International Public Policy, Osaka University.

Sjöberg, L. and Engelberg, E., 2005. International Review of Sociology/Revue Internationale de Sociologie 15, 327-362.

Sorrell, S., 2007. The Rebound Effect: An Assessment of the Evidence for Econ-omyWide Energy Savings from Improved Energy Efficiency. A Report Produced by the Sussex Energy Group for the Technology and Policy Assessment Function of the UK Energy Research Centre. Sussex: UK Energy Research Centre.

Stern, P.C., 2000. Toward a Coherent Theory of Environmentally Significant Behavior, Journal of Social Issues, 56, 407-424.

Sutherland, R.J., 1991. Market barriers to energy efficiency investments. The Energy Journal, 12, 15-34.

Torgler, B., García-Valiñas, M.A., Macintyre, A., 2008. Differences in preferences towards the environment: the Impact of a gender, age and parental effect. Fondazione Eni Enrico Mattei, Nota di lavorno: 18.2008.

Torgler, B., García-Valiñas, M.A., 2007. The determinants of individuals' attitudes towards preventing environmental damage. Ecological Economics, 63, 536-552

Truffer, B., Markard, J., Wüstenhagen, R., 2001. Eco-labeling of electricity - strategies and tradeoffs in the definition of environmental standards. Energy Policy, 29, 885-897.

Van den Bergh, J. C. J. M., 2011. Energy conservation more effective with rebound policy. Environmental \& Resource Economics, 48, 43-58.

Van Raaij, F., Verhallen, T., 1983. A behavioral model of residential energy use. Journal of Economic Psychology, 1, 39-63.:

Viklund, M. 2004. Energy policy options - from the perspective of public attitudes and risk perceptions. Energy Policy, 32, 1169-1171. 
Waide, P., 1998. Monitoring of energy efficiency trends of European domestic refrigeration appliances, final report. PW Consulting for ADEME on behalf of the European Commission (SAVE). PW Consulting: Manchester; 1998.

Waide, P., 2001. Monitoring of energy efficiency trends of refrigerators, freezers, washing machines and washer-driers sold in the EU, final report. PW Consulting for ADEME on behalf of the European Commission (SAVE). PW Consulting: Manchester; 2001

Walsh, M., 1989. Energy tax credits and housing improvement. Energy Economics, 11, $275-284$.

Weber, C., Perrels, A., 2000. Modelling lifestyle effects on energy demand and related emissions. Energy Policy, 28, 549-566.

Whitehead, J.C., 1991. Environmental interest group behaviour and self-selection bias in contingent valuation mail surveys. Growth and Change, 22, 10-21.

Wilson, C., Dowlatabadi, H., 2007. Models of Decision Making and Residential Energy Use. Annual review of environment and resources, 32, 169-203.

Young, D., 2008. When do energy-efficient appliances generate energy savings? Some evidence from Canada. Energy Policy, 36, 34-46. 
Table A.1: Year of Country Implementation of EU Energy Consumption Labeling Directives

\begin{tabular}{|c|c|c|c|}
\hline & $\begin{array}{l}\text { Refrigerators and } \\
\text { Freezers }\end{array}$ & Washing Machines & Dishwashters \\
\hline Belgium & 1999 & 1999 & 1999 \\
\hline Bulgaria & 2006 & 2006 & 2006 \\
\hline Czech Republic & 2004 & 2004 & 2004 \\
\hline Denmark & 1995 & 1996 & 1999 \\
\hline France & 1995 & 1996 & 1998 \\
\hline Germany & 1998 & 1998 & 1998 \\
\hline Greece & 1996 & 1997 & 1997 \\
\hline Hungry & 2002 & 2002 & 2002 \\
\hline Norway & 1996 & 1996 & 1996 \\
\hline Portugal & 1995 & 1996 & 2000 \\
\hline Romania & 2001 & 2001 & 2001 \\
\hline
\end{tabular}

